\title{
SfII
}

\section{Studies in Second Language Learning and Teaching}

Department of English Studies, Faculty of Pedagogy and Fine Arts, Adam M ickiewicz University, Kalisz

\section{Past and future research agendas on writing strategies: Conceptualizations, inquiry methods, and research findings}

\author{
Rosa M. Manchón \\ University of M urcia, Spain \\ manchon@um.es
}

\begin{abstract}
This paper offers a retrospective narrative review of research on L2 writing strategies and a prospective discussion of potential theoretical and pedagogical relevant lines of inquiry to be explored in future research agendas. The retrospective analysis will synthesize the main trends observed in the conceptualization of writing strategies as well as central directions followed in empirical research in the domain. The prospective discussion tries to advance research agendas on the basis of several observations about L2 writing that are presented as key points to be considered when analyzing existing or thinking about future research in the domain. Special mention will be made of future research avenues centrally concerned with theoretical and empirical questions on the manner in which strategic behavior during writing and during written corrective feedback processing may foster language learning. It will be suggested that following this route can result in interesting and profitable synergies between research on language learning strategies and recent SLA-oriented $\mathrm{L} 2$ writing research initiatives on the language learning potential associated with L2 writing.
\end{abstract}

Keywords: feedback processing; learning-to-write; L2 writing; problem solving; writing-to-learn-language; strategies 


\section{Introduction}

The analysis of writing strategies presented in this contribution to the special issue builds on, expands, and updates previous narrative and synthetic reviews of this research domain published over the course of the last 15 years. It might be relevant to note that these previous reviews were included in a book on language learning strategies (Manchón, Roca de Larios, \& Murphy, 2007), a book on bilingualism (Manchón, 2013) and three collective works on writing (Manchón, 2001; Roca de Larios, Coyle, \& Nicolás-Conesa 2016; Roca de Larios, M urphy, \& Marín, 2002).

Coincidentally, a number of key developments have taken place in second language (L2) writing scholarship during these 15 years, and these bear important implications for any critical account of what is already known and remains to be known about writing strategies. Therefore, the present analysis tries to incorporate these developments and resulting implications, and this explains the orientation and structure of the article. In essence, I offer both a retrospective, narrative review of existing research, and a prospective analysis of what I consider to be theoretically and pedagogically relevant future disciplinary developments in the study of $\mathrm{L} 2$ writing strategies. The retrospective analysis will synthesize the main directions followed in the conceptualization of writing strategies, central lines of inquiry and main research methods employed in relevant cognitively-oriented research strands. Complementing this retrospective analysis, the prospective discussion will take stock of a number of key developments in L2 writing scholarship at large and it will offer proposals for advancing research agendas, especially concerning theoretically- and pedagogically-relevant questions on the manner in which strategic behavior during writing and during written corrective feedback processing can foster language learning.

\section{Research on writing strategies: Looking back}

\subsection{Trends in conceptualizations}

In our synthesis of research on writing strategies (Manchón et al., 2007), we concluded that work in the field (including cognitively-oriented and socially-oriented research strands) was characterized by: (i) a plethora of conceptualizations explicitly or implicitly guiding research, (ii) a diversity of approaches to empirically operationalizing and investigating the phenomenon, and (iii) an equal diversity of taxonomies of strategies. In Manchón (2001) and Manchón et al. (2007) an attempt was made to make sense of these diverse approaches and positions, and a distinction between a broad and a narrow characterization of strategies was proposed. The broad conceptualization would equate strategies with just any action or process implemented 
in the act of writing, whereas narrow conceptualizations of the phenomenon equate strategies with specific writing actions and behaviors.

In general terms, these broad and narrow conceptualizations are linked to the linguistic, social, and cognitive dimensions of $L 2$ writing, three complementary angles that reflect the multi-faceted nature of $\mathbf{L} 2$ writing (see Leki, Cumming, \& Silva, 2008). A linguistic perspective is adopted when the focus is on the characteristics of the texts $L 2$ writers produce. Viewing writing through a socio-cultural and socio-cognitive lens, in contrast, is rooted in the consideration of writing as a socially-situated activity and hence it takes into account the myriad of contexts where writers write and learn to write. Finally, in order to produce their texts, writers engage in a number of mental actions and processes, whose study represents the more cognitively-oriented, processing dimension of writing research.

Given these diverse dimensions of $L 2$ writing, and hence of writing strategies, a whole range of theoretical frameworks have guided scholarly work in this area. These include (but are not limited to) linguistic theories, genre theories, theories of literacy development, cognitive models of $L 1$ writing, the problem-solving paradigm in cognitive psychology, research on $L 2$ language learning and language use strategies, and theories of self-regulation, the latter being a prominent paradigm in recent studies (see, for instance, Csizér \& Tankó, 2015; Teng \& Zhang, 2016). The tripartite distinction among linguistic, social, and cognitive dimensions of writing can help us discern patterns and tendencies in the conceptualizations guiding the available research on writing strategies.

\subsubsection{Linguistic perspective}

Two main lines of inquiry have approached the study of strategies in the domain of writing from a linguistic perspective. One has focused on the description of and/or instruction on the mechanisms to be used in producing different kinds of writing in terms of features, patterns, and forms of organization characteristic of various text types and genres (see Abbuhl, 2012; M aier, 1992; Vergaro, 2004, for examples; see also contributions to Plo Alastrué \& Pérez-Llantada, 2015). The other prominent trend is more closely linked to the area of biliteracy and includes analyses of multilingual strategies and resources characteristic of biliteracy development, as well as debates of a more ideological nature on issues related to the promotion of and commitment to biliteracy (see Manchón, 2016, 2017; Palfreyman \& van der Walt, 2017).

Although this linguistic approach to the study of strategies is not going to be further reviewed in the present article, it is relevant to make passing reference to a current issue of debate in $\mathrm{L} 2$ writing studies (which was not covered in previous ones) that has obvious connections to writing strategies and, more 
precisely, to the analysis of strategies in the area of academic writing. I am referring to ongoing debates on the once denounced linguistic inequality/disadvantage of additional language writers, especially publishing academics, a debate more recently referred to by Hyland as the "linguistic advantage orthodoxy" (Hyland, 2015, 2016a). The point I would like to raise is that it might be somewhat problematic to talk about "L2 writing strategies" in this domain because, as repeatedly mentioned in the relevant literature, academic writing is not part of anyone's native language capacities. In fact, a recent development in this area is the increasing relevance accorded to expertise rather than nativeness when considering multilingual writers' literacy acquisition and practices. As argued by Hyland (2016a; see also Casanave, 2017), being a native speaker per se (i.e., without the necessary investment, training, and experience) does not guarantee possession of the "necessary know-how and experience to produce publishable papers" (Hyland, 2016a, p. 61-62), whereas experience and training can potentially make L2 users "academically bilingual" (p. 62). This position has nevertheless been contested recently. To encounter the full debate, see the response by Politzer-Ahles et al. (2016) to Hyland (2015, 2016a), and read Hyland's (2016b) response.

For our current purposes, the important point to be made is the relevance of applying a critical lens when assessing whether or not some research strands on writing strategies undertaken within this linguistic perspective in effect look into strategies critically linked to writing in an additional language or, rather, the phenomena in focus are general strategies used when approaching the writing of academic texts for diverse purposes and audiences, regardless of the status that the language in which the text is written has in the writer's total linguistic repertoire. A case in point is the abundant research on intertextuality and plagiarism (see Pecorari, 2016a, 2016b, for recent comprehensive reviews), often viewed as studies on how $L 2$ writers learn to incorporate other sources into their own writing, when in effect more often than not the real research foci are general intertextuality strategies that need to be mastered by anyone learning to write academic texts and becoming acculturated into academia in any of the languages that form part of one's own linguistic repertoire.

\subsubsection{Socio-cognitive and socio-cultural perspectives}

Closely linked to the point made in the last paragraph, a socio-cultural and sociocognitive perspective on strategies looks at the interaction between the social and the cognitive dimensions of writing in the development of $L 2$ writers' strategic competence (see Roca et al., 2016). Accordingly, under this paradigm, strategies are viewed as actions implemented by 22 writers to respond to the demands encountered in the discourse community where they write and learn 
to write. An important concern in this strand has been to ascertain the manner in which strategic behavior is mediated by the social context in which writing takes place (e.g., Cumming, 2006; Lei, 2008; Leki, 1995, 2011; Sasaki, 2004, 2007; Spack, 1997, for representative examples). Research in the area has been framed in socio-cognitive views of literacy development as well as goal theories in educational psychology. Due to space limitations, this approach to the study of writing strategies will not be part of the analysis that follows (but see reviews in Leki et al., 2008; M anchón et al., 2007).

\subsubsection{Cognitive perspectives}

Strategies in the domain of writing have also been approached from a more cognitive perspective, this being the main strand in focus in the present review. Seen from this angle, strategies refer to a whole array of phenomena that, at one end, are made to coincide with general macro-writing writing processes (i.e., planning, formulation, revision, and monitoring) and, at the other end, with specific actions implemented within those macro-writing processes, including control mechanisms of one's writing behavior as well as problem-solving devices (as reviewed in M anchón, 2013; Manchón et al., 2007; Roca de Larios et al., 2016). The list of specific strategies inspected in research include, among others (in alphabetical order): avoidance, backtracking, evaluation, reformulation, recourse to the $L 1$, rehearsing, restructuring, or rhetorical refining. This variation in the range of actions subsumed under the category of strategies explains the long list of terms used interchangeably with that of strategies, among others, behaviors, operations, procedures, processes, skills, or techniques (see M anchón et al., 2007, for references).

The most recent development in the conceptualization of strategies from a cognitive perspective is associated with Macaro's work. Based on his previous conceptualization of strategic behavior from the perspective of the manner in which clusters of strategies are combined and evaluated against language users' own goals and task demands (M acaro, 2006), his basic argument is that: (a) we should expect important individual variation in the way in which L2 writers interpret the goal of the task (which, in turn, depends on their own goal-setting in relation to the task) and, accordingly, (b) we should also expect variation in the degree of effectiveness of the strategic behavior adopted. This view is very much related to the concept of task representation in writing, which is crucial in any consideration of L2 writers' strategic behavior (see M anchón, 2014). 


\subsection{Cognitively-oriented research on writing strategies: Directions in research agendas and empirical findings}

As shown in Figure 1, three main directions can be discerned in cognitively-oriented empirical work on writing strategies: (a) cross-sectional and longitudinal explorations of (antecedents and effects of) strategy use; (b) studies looking into the effect of strategy instruction; and, finally, (c) validations of writing strategies questionnaires.

STRAND 1. USE OF WRITING STRATEGIES: M EDIATING FACTORS AND EFFECTS

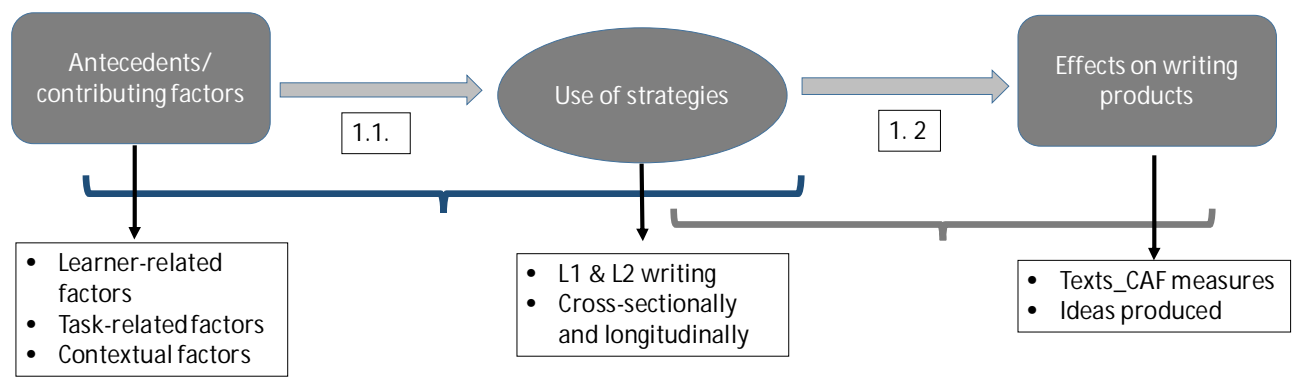

STRAND 2. STRATEGY INSTRUCTION

STRAND 3. VAUDATION OF WRITING STRATEGIES QUESTIONNAIRES

Figure 1 Overview of empirical research on strategies used while writing

In what follows I shall briefly review main research directions in these domains and will point to representative studies within each strand, including both work covered in previous reviews, as well as studies published since.

\subsubsection{Strand 1: Strategy use - mediating factors and effects}

The first (and main) strand of research into writing strategies corresponds to an important number of cross-sectional and longitudinal studies that have tried to shed light on the strategies used by $\mathbf{2}$ users, including strategy use in L2 writing as well as comparisons of strategy use in first language (L1) and L2 writing. This body of work has also looked into the learner-related, task-related, and contextrelated variables influencing strategy deployment (1.1. in Figure 1), on the one hand, and into the effects of strategy deployment on several ideational and linguistic dimensions of the texts produced (1.2. in Figure 1), on the other.

The main groups of $L 2$ writers in focus in this body of work have been second and foreign language university students (e.g., Csizér \& Tankó, 2015; M anchón et al., 2009; Sasaki, 2004, 2007), although some studies have investigated professional 
writers (e.g., Beare \& Bourdages 2007) and secondary school students (e.g., M aarof \& M urat, 2013; Schoonen et al., 2009, 2011; Simeon, 2016; Tillema, 2012; Tillema, van den Bergh, Rijlaarsdam, \& Sanders, 2011). Given the nature of research preoccupations and the fact that the phenomena under the spotlight are not always directly accessible, data collection procedures have included introspective techniques (e.g., think-aloud protocols or stimulated recalls), survey data collection procedures (i.e., questionnaires or interviews), text analysis, and computerized tracking (e.g., keystroke logging), often triangulating data from several sources. M ost of this research is cross-sectional in nature, although there are solid longitudinal studies in the area (e.g., Sasaki, 2004, 2007, 2009; Spack, 1997).

In studies concerned with the antecedents of strategy deployment, the main independent variables whose effect on strategy use is measured include learner-related, task-related, and context-related variables. As for learner-related variables, plenty of scholarly attention has been paid to $L 2$ proficiency (e.g., Cumming 1989; Manchón et al., 2009; Sasaki, 2000, 2004), and degree of writing competence or expertise, with important differences reported between skilled and unskilled writers (e.g., Chien, 2012; Cumming, 1989; Raoofi, Binandeh, \& Rahmani, 2017). These two factors have been found to influence the quantitative and qualitative use of strategies, as well as the effect that a given strategy may have (see Roca de Larios et al., 2002, for a thorough review). Additional writer-related variables investigated include gender (M cM ullen, 2009), motivation, (e.g., Csizér \& Tankó, 2015), or the writer's mental model of writing, that is, the set of conceptions and beliefs that guide writing performance (e.g., Cumming, 1989; Devine, Raley, \& Boshoff, 1993; M anchón et al., 2009; Nicolás-Conesa et al., 2014).

Regarding task-related variables, earlier studies looked into how more and less complex tasks influenced cognitive activity while writing (cf. Manchón et al., 2009; Roca de Larios et al, 1999, 2001). For instance, argumentative tasks were found to trigger more decisions involving simultaneous thinking about gist and language than letter writing (Cumming, 1989), and backtracking behavior was found to differ in narrative and argumentative tasks (M anchón et al., 2000). M ore recently, several studies (Ong, 2013, 2014; Ong \& Zhang, 2010) framed in second language acquisition (SLA) theories of task complexity (essentially Robinson's cognition hypothesis; see Robinson, 2011, for the latest formulation), have looked into various task complexity factors contemplated in the cognition hypothesis (such as planning time, or the availability of writing assistance in terms of ideas to be included in the text or its macro-structure) on writing processes (metacognitive processes, Ong, 2014) and ideational and linguistic characteristics of the resulting texts (quality and quantity of ideas in the text [Ong, 2013], or fluency and lexical complexity [Ong \& Zhang, 2010]). Another task-related factor found to mediate strategy use is time, as reported, for instance, by Sasaki 
(2004) with respect to the strategies of local or global planning and use of the L1, by Porte $(1995,1996)$ with respect to revision behavior, and by Tillema et al. (2011) with respect to the temporal distribution of six (meta)cognitive activities (reading the assignment, planning, text production, reading own text, evaluating own text, and revising).

Finally, context-related variables have also been found to mediate strategy use. Special research attention has been devoted to the influence of previous L1/ L2 literacy and educational experience (cf. Bosher, 1998; Cumming, 1989; Kobayashi \& Rinnert, 1992; Porte, 1995; Sasaki, 2000, 2004; Sasaki \& Hirose, 1996; Zainuddin \& Moore, 2003), as well as to the strategies used when transferring previous genre knowledge and expanding genre repertoires across contexts of learning (e.g., Leki, 2011). Another line of research has looked into strategy use in study-abroad stays (e.g., Sasaki, 2004, 2007).

An abundant body of work also exists in the other two areas of research in Strand 1 depicted in Figure 1, namely, use of strategies and effects of strategy use on writing products, including both ideational and linguistic characteristics of the texts produced (see Roca de Larios et al., 2016, for a fuller analysis). Research concerned with the qualitative and quantitative use of strategies in L2 writing has provided holistic descriptions of $L 2$ writers' composing behavior either (a) globally (cf. Cumming 1989; M anchón et al, 2009; Sasaki, 2000, 2002) or (b) with reference to just one macro-writing process, be this planning (cf. Akyel, 1994; Manchón \& Roca de Larios, 2007a), formulation (e.g., Chenoweth \& Hayes, 2001; Roca de Larios et al., 2001; Zimmermann, 2000), or revision (e.g., Porte, 1995, 1996, 1997; Sengupta, 2000; Takagaki, 2003). Some taxonomic approaches in the general literature of strategies have been used in the classification of writing strategies (see the review in Manchón et al., 2007), and a more recent trend in research has been framed in theories of self-regulation (e.g., Csizer \& Tang, 2015).

Studies of strategy deployment also include comparative analyses of cognitive activity in L1 and L2 writing (Beare \& Bourdages, 2007; Chenoweth \& Hayes, 2001; Schoonen et al., 2003; Stevenson, Schoonen, \& De Gloper, 2006; Thorson, 2000; Tillema, 2012; Van Weijen, 2009), an area in which diverse and contradictory findings exist (see Manchón, 2013). An important empirical preoccupation in this domain has been the transfer of strategies across languages, with special attention being paid to whether or not writing skills acquired in one's L1 can be transferred to the L2 condition, as well as the potential inhibiting role that L2 proficiency may have in this process. In our analysis of this research (Manchón et al., 2007), we concluded that: (a) the empirical evidence shows that writing strategies transfer across languages, although quantitative use may differ from the $L 1$ to the $L 2$, and (b) the transfer of strategies across languages is mediated by both writer-related factors (e.g., proficiency and one's own goals) 
and task-related factors (see Manchón et al., 2007, for a fuller analysis). More recent research has shed further light on the interaction between proficiency and writing expertise by adding a further piece of the puzzle. Thus, we found a more consistent correspondence between L1 and L2 performance at lower and advanced proficiency levels than at intermediate levels of $L 2$ proficiency (see Manchón et al., 2009). Our research showed that lower proficiency writers showed similarities in the way in which they approached their writing in their L1 and L2: They engaged in very superficial processing in their L1 writing, which they transferred to their $L 2$ writing, for which their low level of L2 proficiency was sufficient. The advanced participants could also maintain their level of "expert-like" $\mathrm{L} 1$ writing performance in the $\mathrm{L} 2$ condition because their $\mathrm{L} 2$ proficiency allowed them to do so. In contrast, the intermediate participants, also expert writers in their $\mathrm{L} 1$, had not reached the necessary level of linguistic competence in their L2 that would have allowed the transfer of their $L 1$ writing skills to the $L 2$ condition.

The continuous interest in shedding light on the interaction or separation of language abilities and writing skills has more recently resulted in explorations of the way in which multilingual writers make use of their various knowledge resources and skills when approaching the writing of texts in the various languages that form their linguistic repertoire (see Manchón, 2013, for further elaboration).

\subsubsection{Strand 2: Strategy instruction studies}

The second strand of research in Figure 1 corresponds to research on writing strategy instruction, an area of research conspicuously almost absent from Chamot's (2005) review of language learning strategy instruction. What is more, in his meta-analysis of strategy instruction research, Plonsky (2011) noted an imbalance in the attention paid to the four language skills in strategy instruction research and concluded that "further research [is] needed on the effects of SI on writing" (Plonsky, 2011, p. 1017).

Although scant as compared to the more abundant research on speaking, listening and reading strategy training, the available studies on writing strategy instruction include both comprehensive longitudinal instructional programs (the most comprehensive one being Olson \& Land, 2007; see also De Silva, 2014) as well as training approaches in the use of specific strategies, such as dictionary use (e.g., Bishop, 2000, 2001), lexical fluency (van Gelderen, Oostdam, \& Schooten, 2011), working memory strategies (Ransdell, Lavelle, \& Levy, 2002), metacognitive self-regulation strategies (Nguyen $\& \mathrm{Gu}, 2013$ ), planning and revision (Ching 2002), revision strategies (Sengupta, 2000), or peer feedback provision (Rahimi, 2013). Collectively, studies either of descriptive nature or following pre-test post-test experimental research designs have measured (and provided empirical 
evidence for) the effects of strategy use on the characteristics of writing products and on a rage of learner-related attributes, including writers' beliefs and conceptions of writing, their self-determination, confidence and autonomy, and their global approaches to writing.

As could be expected, some of these studies have been conducted in the context of academic writing programs (e.g., De Silva, 2014; Nguyen \& Gu, 2013), although, in contrast to other strands in writing strategy research, a significant part of these training programs was addressed to secondary students. For instance, in Van Gelderen, Oostdam, and Schooten's (2011) classroom experimental study with secondary school Dutch students of English, the researchers measured the effect of training students in lexical retrieval of familiar words (as compared to a group of writers that did not have the benefit of lexical fluency training) on text quality. Along similar lines, in another experimental study, Snellings, Van Gelderen, and De Glopper (2004a) implemented a computerized training program for improving fluency of lexical retrieval in a secondary school classroom. They then measured the effects of enhanced lexical retrieval on several aspects of $L 2$ narrative written by their Dutch secondary education students. In a more comprehensive cognitively-oriented strategy instructional program in reading and writing, Olson and Land (2007) reported the implementation of a 7-year instructional approach conducted by 55 secondary school teachers with English language learners in 13 secondary schools in large urban district in California. The researchers found robust empirical evidence for the effects of the cognitive strategies instruction on written products, which they attributed to a combination of variables that together contributed to the quality of the instructional program: its comprehensiveness ("teachers and students were exposed to an extensive set of cognitive strategies and a wide array of curricular approaches to strategy use," p. 269), as well as the density of the treatment and its duration (8 years of exposure to curriculum-embedded instruction).

\subsubsection{Strand 3: Validating writing strategy questionnaires and research instruments}

Finally, the third strand in Figure 1 corresponds to research initiatives aimed at validating writing strategy questionnaires as well as research instruments directly or indirectly related to writing strategies. These initiatives include Cheng's (2004) validation of a writing anxiety scale, Petric and Czárl's (2003) validation of a strategy writing questionnaire, Snellings, van Gelderen and de Glopper's (2004b) validation of a test of second language written lexical retrieval and, more recently, Teng and Zhang's (2016) validation of a strategy questionnaire. 


\section{Research on writing strategies: Looking ahead}

It is pertinent to reflect on several key points about L2 writing that ought to be central in the analysis of future work in the field.

\subsection{2 writing purposes and conditions. Implications for future research on strategies}

Any consideration of past and future research on strategies and strategic behavior in the written modality needs to acknowledge that $L 2$ writing is not a unitary, monolithic phenomenon. Much to the contrary, the purposes, conditions, and outcomes of writing in an additional language are varied, which adds an extra layer of complexity to thinking about and researching strategies in this language modality. Hence, as Macaro (2014) has recently observed, "different tasks demand different clusters of strategies" (p. 56).

In a recent contribution to a collective volume on tasks and writing (M anchón, 2014), I suggested that L2 writing should be made to encompass a whole range of conditions that, to a minimum, include performing writing in:

individual and collaborative writing, in time-constrained and time-unlimited conditions, in both pen-and-paper and computer-mediated environments, totally or partially performed within and/or outside the confines of the language classroom, with and without the availability of (printed or electronic) external sources, and, importantly, with and without the availability of (different types of) feedback provided at different points in the composing process, which may serve different functions. (M anchón, 2014, pp. 29-30)

It is relevant to consider this wide range of variables when revisiting the available research on writing strategies and when thinking about future research agendas. Hence, I would suggest that past and future work in the field ought to be inspected in terms of whether or not this collective body of work has accounted/ought to account for strategic behavior in several conditions. First, it is relevant to study strategy use during writing as well as during written corrective feedback (WCF) processing, the latter being an almost uncharted territory in the otherwise abundant research on WCF. Second, it would be pertinent to look into writing strategies in individual and collaborative writing conditions, the latter, once again, are hardly present in mainstream explorations of writing strategies (but see Simeon, 2016), while, at the same time, the study of strategies has not been a central concern in collaborative writing research (see Storch, 2016, for a recent comprehensive review). Third, more empirical attention should be paid to strategic behavior in traditional pen-and-paper conditions and in computer-mediated environments, a distinction that has not featured prominently in theoretical and empirical research on writing strategies. Similarly, given the attested time-dependency of both strategy 
use and the linguistic processing while writing that may be conducive to language learning (see Manchón \& Roca de Larios, 2007b), time-on-task conditions ought to be a key variable to feature more prominently in future investigations. Finally, an important parameter to be included in future investigations of writing strategies relates to whether $L 2$ writers engage in writing using their own and/or external resources, the former being more prominent in research and the latter constituting a central preoccupation in studies of dictionary use in writing (cf. Christianson, 1997) and in the abundant research on writing from sources (as reviewed in Pecorari, 2016a, 2016b), including electronic sources (see Stapleton, 2005).

Accordingly, a first concluding remark to be made is to acknowledge that the extant body of research on strategies in the domain of writing covers only a few pieces of what is a much bigger puzzle, hence the relevance of expanding future research agendas.

\subsection{Dimensions of $L 2$ writing: Learning to write and writing to learn language. Implications for the study of writing strategies}

As discussed in some recent work (e.g., M anchón, 2011), the learning and teaching of $L 2$ writing may be guided by two main purposes, generally referred to as "learning to write" and "writing to learn," the latter including learning both content and language. In learning-to-write conditions, writing is learned and taught as an end in itself, the ultimate aim being the development of (multi)literacy for a variety of personal, social, academic, and/or professional purposes. In contrast, in writing-tolearn conditions, writing would be learned and/or taught as a means to an end, including both learning disciplinary subject-matter in the content areas, on the one hand, and engaging in writing as a tool for language learning, on the other.

Important for our current purposes, a key disciplinary development in L2 writing studies corresponds precisely to the consideration of the writing-tolearn language (WLL) dimension. This is a rapidly expanding research strand at the interface between SLA and L2 writing that has been instrumental in the consideration of $L 2$ writing as a site for language learning. Research efforts in this area have materialized in a body of publications collectively concerned with theorizing the language learning potential of $L 2$ writing and feedback processing, setting a challenging future research agenda and providing empirical evidence on the manner in which writing itself and the processing of feedback can contribute to developing 12 knowledge and competences (see Bitchener, 2012; Bitchener \& Storch, 2016; Byrnes \& Manchón, 2014; Manchón, 2011; M anchón \& Williams, 2016; Roca de Larios, 2013; Williams, 2012; Zhang, 2013).

Concerning the learning-to-write/writing-to-learn-language dichotomy in its application to research on strategies, several observations are pertinent. To start 
with, most of the available empirical work on writing strategies has explicitly or implicitly looked into strategies from the perspective of the mechanisms used when approaching the writing of texts, therefore being closely linked to the learning-towrite dimension of $\mathrm{L} 2$ writing (this is evident in the preceding analysis as well as in previous reviews of writing strategies in Manchón, 2013; M anchón et al., 2007; Roca de Larios et al., 2002, 2016). Therefore, new avenues for future research agendas ought to be concerned with the manner in which strategic behavior during writing and during WCF processing can be conducive to language learning. Crucial in these future developments are questions of learners' depth of problem-solving and depth of processing, variables that have been proposed as being centrally related to any potential language learning associated with the acts of writing and WCF processing (see Bitchener \& Storch, 2016; Manchón \& Roca, 2007b; M anchón \& Williams, 2016). We therefore need new studies within Research strands 1 and 2 in Figure 1 mentioned in an earlier section, these being studies that relate the concept of strategy use and strategic behavior to central concerns in the cognitively-oriented research on the WLL dimension of $L 2$ writing. In this respect, it is important to note that the available research on the WLL dimension of $L 2$ writing and WCF processing has already started to establish links with central preoccupations in cognitively-oriented SLA disciplinary developments, including, for instance, the role of attentional processes in SLA, or the acquisition and use of explicit and implicit knowledge (see Bitchener \& Storch, 2016; Manchón \& Williams, 2016). Yet, to my knowledge, such a link between WLL preoccupations and cognitively-oriented research on strategies is uncharted territory, with the notable exception of Macaro's (2014) discussion of strategic behavior and writing task execution, a position mentioned in earlier sections (see also García-Hernández, 2017; García-Hernández, Roca de Larios, \& Coyle, 2017).

It follows that it is relevant to acknowledge the theoretical and pedagogical relevance of investigating writing strategies from the perspective of $L 2$ users' attempts to develop their writing expertise (learning-to-write), as well as from the perspective of $L 2$ users' efforts to make the most of their writing experience for L2 development (writing-to-learn-language). The latter is especially important if, as has been repeatedly claimed in the strategy literature the ultimate aim of strategy research is to develop knowledge that can be useful in improving language learning and teaching in second and foreign language classrooms.

\section{Concluding remarks}

In short, the consideration of (a) whole range of purposes, conditions and outcomes of writing (i.e., writing in individual/collaborative conditions, with/without the availability of feedback, in diverse time-on-task conditions); (b) the various dimensions of writing (i.e., learning to write/ writing to learn content/ writing to 
learn language); and (c) the tripartite consideration of writing as a linguistic, social and cognitive phenomenon provide convincing evidence of the complexity inherent to investigating strategies in the domain of writing. At a minimum, three key concerns should be made central in future work on writing strategies. First, writing strategies cannot be narrowly conceived as being related solely to the development of writing abilities; rather, writing strategies should be linked to both learning-to-write and writing-to-learn purposes, conditions, and settings. Second, writing strategies ought to be linked to both the act of writing before and after receiving WCF, the latter implying the development of strategies to process and make use of WCF. As for writing itself, concepts of writing strategies ought to go beyond individual, solitary acts of writing and be made to encompass strategic behavior in both individual and collaborative writing conditions. Thirdly, if it is accepted that writing is a linguo-cognitive activity embedded in particular social settings, writing strategies can be viewed from a linguistic perspective and from a cognitive perspective, the phenomenon hence meaning different things in the two domains and, consequently, opening the possibility of being informed by a range of theories. In addition, and closely related to the socially-situated nature of learning and teaching $\mathrm{L} 2$ writing, a central preoccupation in future work on writing strategies (also part of SLA-oriented L2 writing research at large) ought to be the study of strategies in contexts in which instructed $L 2$ learners (especially pre-university $L 2$ users in foreign language settings) develop simultaneously their writing abilities in all the languages of their curriculum (i.e., their L1 and all the L2s that may form part of their school curriculum) and their $L 2$ general proficiency (see Manchón \& Williams, 2016).

To conclude, it is hoped that the preceding retrospective narrative review of research on $L 2$ writing strategies has made evident the wealth of available perspectives on writing strategies, and that the prospective discussion of potential theoretical and pedagogical relevant lines of inquiry shows profitable and worthy avenues to be explored in future research agendas. Following these routes can result in interesting and profitable synergies between research on language learning strategies and recent SLA-oriented $\mathbf{2}$ writing research initiatives centrally concerned with the language learning potential associated with $\mathrm{L} 2$ writing and written corrective feedback processing.

\section{Acknowledgements}

The review presented in this article is part of the research activities conducted within a program of research on L2 writing financed by the Spanish M inistry of Economy and Competitiveness (Research Grant FFI2016-79763-P). 
References

Abbulh, R. (2012). Using self-referential pronouns in writing: The effect of explicit instruction on $L 2$ writers at two levels of proficiency. Language Teaching Research, 16(4), 501-518.

Akyel, A. (1994). First language use in EFL writing: Planning in Turkish vs. planning in English. International Journal of Applied Linguistics, 4(2), 169-196.

Beare, S., \& Bourdages, J. (2007). Skilled writers' generating strategies in L1 and L2: An exploratory study. In M . Torrance, L Van Waes, \& D. Galbraith (Eds.), Writing and cognition: Research and applications (pp. 151-161). Amsterdam: Elsevier.

Bishop, G. (2000). Developing learner strategies in the use of dictionaries as a productive language learning tool. Language Learning Journal, 23, 58-62. Bishop, G. (2001). Using quality and accuracy ratings to quantify the value added of a dictionary skills training course. Language Learning Journal, 24, 62-69. Bitchener, J. (2012). A reflection on "the language learning potential" of written CF. Journal of Second Language Writing, 22, 348-363.

Bitchener, J., \& Storch N. (2016). Written corrective feedback for L2 development. Bristol, UK: Multilingual Matters.

Bosher, S. (1998). The composing processes of three Southeast Asian writers at the post-secondary level: An exploratory study. Journal of Second Language Writing, 7, 205-241.

Byrnes, H., \& M anchón, R. M. (Eds.). (2014). Task-based language learning: Insights from and for L2 writing. Amsterdam: John Benjamins.

Casanave. C. (2017). Epilogue. In In J. Bitchener, N. Stroch, \& Wette, R. (Eds), Teaching writing for academic purposes to multilingual students: Instructional approaches (pp. 203-215). London: Routledge.

Chamot, A. (2005). Language learning strategy instruction: Current issues and research. Annual Review of Applied Linguistics, 25, 112-130.

Cheng, Y-S. (2004). A measure of second language writing anxiety: Scale development and preliminary validation. Journal of Second Language Writing, 13, 313-335.

Chenoweth, A. \& Hayes, J. (2001). Fluency in writing: Generating text in L1 and L2. Written Communication, 18(1), 80-98.

Chien, S.-C. (2012). Students' use of writing strategies and their English writing achievement in Taiwan. Asia Pacific Journal of Education, 32(1), 93-112.

Ching, L. C. (2002). Strategy and self-regulation instruction as contributors to improving students' cognitive model in an ESL program. English for Specific Purposes, 21, 261-289.

Csizér, K., \& Tankó, G. (2015). English majors' self-regulatory control strategy use in academic writing and its relation to $L 2$ motivation. Applied Linguistics, 38(3), 1-20. 
Cumming, A. (1989). Writing expertise and second language proficiency. Language Learning, 39, 81-141.

Cumming, A. (Ed.). (2006). Goals for ESL writing improvement in ESL and university courses. Amsterdam: John Benjamins.

De Silva, R. (2015). Writing strategy instruction: Its impact on writing in a second language for academic purposes. Language Teaching Research, 19(3), 301-323.

Devine, J., Railey, K., \& Boshoff, P. (1993). The implications of cognitive models in L1 and L2 writing. Journal of Second Language Writing, 2(3), 203-225.

García-Hernández, J. (2017). Analysis of the effects of reformulation as a written corrective feedback technique in English with grade six pupils. Doctoral dissertation, University of M urcia, Spain.

García Hernández, J., Roca de Larios, J., \& Coyle, Y. (2017). Reformulation as a problem-solving space for young EFL writers: A longitudinal study of language learning strategies. In M . P. García-M ayo (Ed.), Learning foreign languages in primary school. Research insights (pp. 193-222). Bristol, UK: M ultilingual Matters.

Hyland, K. (2015). Academic publishing: Issues and challenges in the construction of knowledge. Oxford: Oxford University Press.

Hyland, K. (2016a). Academic publishing and the myth of linguistic injustice. Journal of Second Language Writing, 31, 58-69.

Hyland, K. (2016b). Language myths and publishing mysteries: A response to Politzer-Ahles et al. Journal of Second Language Writing, 34, 9-11.

Kobayashi, H., \& Rinnert, C. (1992). Effects of first language on second language writing: Translation versus direct composition. Language Learning, 42(2), 183-215. Lei, X. (2008). Exploring a sociocultural approach to writing strategy research: Mediated actions in writing activities. Journal of Second Language Writing, 17(4), 217-236.

Leki, I. (1995). Coping strategies of ESL students in writing tasks across the curriculum. TESOL Quarterly, 29(2), 235-260.

Leki, I. (2011). Learning to write in a second language. Multilingual graduates and undergraduates expanding genre repertoires. In R. M. M anchón (Ed.), Learning-to-write and writing-to-learn in an additional language (pp. 85109). Amsterdam: John Benjamins.

Leki, I., Cumming, A., \& Silva, T. (2008). A synthesis of research on second language writing in English: 1980-2005. New York: Routledge.

M aartor, N., \& M urat, M. (2013). Writing strategies use by ESL upper secondary school students. International Education Studies, 6(4), 47-55.

$M$ acaro, E. (2006). Strategies for language learning and for language use: Revising the theoretical framework. M odern Language Journal, 90(3), 320-337 Macaro, E. (2014). Reframing task performance: The relationship between asks, strategic behavior, and linguistic knowledge in writing. In $H$. Byrnes $\& R$. 
M. Manchón (Eds.), Task-based language learning: Insights from and for L2 writing (pp. 53-77). Amsterdam: John Benjamins.

Maier, P. (1992). Politeness strategies in business letters by native and non-native English speakers. English for Specific Purposes, 11(3), 189-205.

Manchón, R. M. (2001) Trends in the conceptualizations of second language composing strategies: A critical analysis. International Journal of English Studies, 1(2), 47-70.

Manchón, R. M. (Ed.). (2011). Learning-to-write and writing-to-learn in an additional language. Amsterdam: John Benjamins.

Manchón, R. M. (2013). Writing. In F. Grosjean \& L. Ping (Eds.), The psycholinguistics of bilingualism (pp. 100-115). Malden, M A: Wiley-Blackwell.

M anchón, R. M. (2014). The internal dimension of tasks: The interaction between task factors and learner factors in bringing about learning through writing. In H. Byrnes \& R. M. Manchón (Eds.), Task-based language learning: Insights from and for $L 2$ writing (pp. 27-52). Amsterdam: John Benjamins.

Manchón, R. M. (2016). Language and L2 writing: Learning to write and writing to learn in academic contexts. In K. Hyland \& P. Shaw (Eds.), The Routledge handbook of English for academic purposes (pp. 139-151). New York: Routledge.

Manchón, R. M. (2017). The multifaceted and situated nature of the interaction between language and writing in academic settings. Advancing research agendas. In J. Bitchener, N. Stroch, \& R. Wette (Eds), Teaching writing for academic purposes to multilingual students: Instructional approaches (pp. 183-200). London: Routledge.

Manchón, R. M., \& Roca de Larios, J. (2007a). On the temporal nature of planning in L1 and L2 composing. Language Learning, 27, 549-593.

Manchón, R. M ., \& Roca de Larios J. (2007b). Writing-to-learn in instructed language learning contexts. In E. A. Soler \& M. P. S. Jordá (Eds.), Intercultural language use and language learning (pp. 101-121). Berlin: Springer.

Manchón, R. M., Roca de Larios, J. \& Murphy, L (2000). An approximation to the study of backtracking in $L 2$ writing. Learning and Instruction, 10(1), 13-35.

Manchón, R. M., Roca de Larios, J., \& M urphy, L. (2007). A review of writing strategies: Focus on conceptualizations and impact of the first language. In $A$. Cohen \& E. M acaro (Eds.), Language learner strategies: Thirty years of research and practice (pp. 229-250). Oxford, UK: Oxford University Press.

Manchón, R. M., Roca de Larios, J. \& M urphy, L. (2009). The temporal dimension and problem-solving nature of foreign language composing processes. Implications for theory. In R. M. M anchón (Ed.), Writing in foreign language contexts: Learning, teaching and research (102-124). Clevendon, UK: M ultilingual Matters. 
Manchón, R. M., \& Williams, J. (2016). L2 writing and SLA studies. In R. M. M anchón \& P. K. M atsuda (Eds.), The handbook of second and foreign language writing (pp. 567-586). Berlin: de Gruyter Mouton.

M cM ullen, M. G. (2009). Using language learning strategies to improve the writing skills of Saudi EFL students: Will it really work? System, 37, 418-433.

Nicolás Conesa, F., Roca de Larios, J., \& Coyle, Y. (2014). Development of EFL students' mental models of writing and their effects on performance. Journal of Second Language Writing, 24(1), 1-19.

Nguyen, L. T. C. \& Gu, Y. (2013). Strategy-based instruction: A learner-focused approach to developing learner autonomy. Language Teaching Research, 17(1), 9-30.

Olson, C. B., \& Land, R. (2007). A cognitive strategies approach to reading and writing. Instruction for English language learners in secondary schools. Research in the Teaching of English, 41(3), 269-302.

Ong, J. (2013). Discovery of ideas in second language writing task environment. System, 41(3), 529-542.

Ong, J. (2014). How do planning time and task conditions affect metacognitive processes of L2 writers? Journal of Second Language Writing, 23, 17-30.

Ong, J., \& Zhang, L. (2010). Effects of task complexity on the fluency and lexical complexity in EFL students' argumentative writing. Journal of Second Language Writing, 19(4), 218-233.

Palfreyman, D. M ., \& van der Walt, C. (Eds.). (2017). Academic biliteracies: M ultilingual repertoires in higher education. Bristol, UK: M ultilingual $\mathrm{M}$ atters. Pecorari, D. (2016a). Intertextuality and plagiarism. In K. Hyland \& P. Shaw (Eds.), The Routledge handbook of English for academic purposes (pp. 230-242). New York: Routledge.

Pecorari, D. (2016b). Writing from sources, plagiarm and texual borrowing. In R. M. Manchón \& P. K. Matsuda (Eds.), The handbook of second and foreign language writing (pp. 329-347). Berlin: de Gruyter Mouton.

Petric, B., \& Czárl, B. (2003). Validating a writing strategy questionnaire. System, 31(2), 187-215.

Plo Alastrué, R., \& Pérez-Llantada, C. (Eds.). (2015). English as a scientific and research language. Berlin: De Gruyter M outon.

Plonsky, L. (2011). The effectiveness of second language strategy instruction: A meta-analysis. Language Learning, 61(4), 993-1038.

Politzer-Ahles J. J., S., Holliday, J., Girolamo, T., Spychalska, M., \& Berkson, K. H. (2016). Is linguistic injustice a myth? A response to Hyland (2016). Journal of Second Language Writing, 34, 3-8.

Porte, G. (1995). Estrategias de revisión en expresión escrita en lengua inglesa como segunda lengua. Doctoral dissertation, University of Granada, Spain. 
Porte, G. (1996). When writing fails: How academic context and past learning experiences shape revision. System, 24(1), 107-116.

Porte, G. (1997). The etiology of poor second language writing: The influence of perceived teacher preferences on second language revision strategies. Journal of Second Language Writing, 6(1), 61-78.

Rahimi, M. (2013). Is training student reviewers worth its while? A study of how training influences the quality of students' feedback and writing. Language Teaching Research, 17(1), 67-89.

Ransdell, S., Lavell, B., \& Levy, M. (2002). The effects of training a good working memory strategy on L1 and L2 writing. In S. Ransdell \& M . L. Barbier (Eds.), New directions for research in $L 2$ writing (pp. 133-144). Dordrecht: Kluwer.

Raoofi, S., Binandeh, M. \&, Rahmani, S. (2017). An investigation into writing strategies and writing proficiency of university students. Journal of Language Teaching and Research, 8(1), 191-198.

Riazi, A. (1997). Acquiring disciplinary literacy: A social-cognitive analysis of text production and learning among Iranian graduate students of education. Journal of Second Language Writing, 6(2), 105-137.

Rinnert, C., \& Kobayashi, H. (2016). Multicompetence and multilingual writing. In R. M. Manchón \& P. K. Matsuda (Eds.), The handbook of second and foreign language writing (pp. 365-386). Berlin: De Gruyter Mouton.

Robinson, P. (2011). Second language task complexity, the Cognition Hypothesis, language learning, and performance. In P. Robinson (Ed.), Second language task complexity. Researching the Cognition Hypothesis of language learning and performance (pp. 3-37). Amsterdam: John Benjamins.

Roca de Larios, J. (2013). Second language writing as a psycholinguistic locus for $L 2$ production and learning. Journal of Second Language Writing, 22(4), 444-445. Roca de Larios, J., Coyle, Y., \& Nicolás-Conesa, F. (2016). Focus on writers: Processes and strategies. In R. M. Manchón \& P. K. Matsuda (Eds.), The handbook of second and foreign language writing (pp. 267-286). Berlin: De Gruyter Mouton.

Roca de Larios, J., Marín, J., \& M urphy, L. (2001). A temporal analysis of formulation processes in $\mathrm{L} 1$ and $\mathrm{L} 2$ writing. Language Learning, 51, 497-538.

Roca de Larios, J., M urphy, L., \& M anchón, R. M. (1999). The use of restructuring strategies in EFL writing: A study of Spanish learners of English as a foreign language. Journal of Second Language Writing, 8, 13-44.

Roca de Larios, J., M urphy, L., \& M arín, J. (2002). Critical examination of L2 writing process research. In S. Ransdell \& M. Barbier (Eds), New directions for L2 writing research (pp. 11-48). Dordrecht: Kluwer.

Sasaki, M. (2000). Toward an empirical model of EFL writing processes: An exploratory study. Journal of Second Language Writing, 9(3), 259-291. 
Sasaki, M. (2004). A multiple-data analysis of the 3.5-year development of EFL student writers. Language Learning, 54(3), 525-582.

Sasaki, M. (2007). Effects of study-abroad experiences on EFL writers: A multiple-data analysis. M odern Language Journal, 91, 602-620.

Sasaki, M. (2009). Changes in EFL students' writing over 3.5 years: A socio-cognitive account. In R. M. Manchón (Ed.), Writing in foreign language contexts: Learning, teaching, and researching (pp. 49-76). Clevedon, UK: M ultilingual Matters.

Sasaki, M., \& Hirose, K. (1996). Explanatory variables for EFL students' expository writing. Language Learning, 46(1), 137-174.

Schoonen, R., van Gelderen, A., de Gloper, K., Hulstijn, J., Simis, A., Snelling, P., $\&$ Stevenson, M . (2003). First language and second language writing: The role of linguistic knowledge, speed of processing, and metacognitive knowledge. Language Learning, 54, 165-202.

Schoonen, R., Snellings, P., Stevenson, M., \& Van Gelderen, A. (2009). Towards a blueprint of the foreign language writer: The linguistic and cognitive demands of foreign language writing. In R. M. M anchón (Ed.), Writing in foreign language contexts: Learning, teaching, and research (pp. 77-101). Clevedon, UK: Multilingual Matters.

Schoonen, R., van Gelderen, A., Stoel, R., Hulstijn, J., \& De Glopper, K. (2011). Modeling the development of $L 1$ and EFL writing proficiency of secondaryschool students. Language Learning, 61, 31-79.

Sengupta, S. (2000). An investigation into the effects of revision strategy instruction on L2 secondary school learners. System, 28(1), 97-113.

Simeon, J. (2016). Learner writing strategies of Seychellois ESL (English as a second language) secondary school students. Language, Culture and Social Interaction, 8, 1-11.

Snellings, P., Van Gelderen, A., \& De Glopper, K. (2004a). The effect of enhanced lexical retrieval on L2 writing: A classroom experiment. Applied Psycholinguistics, 55, 175-200.

Snellings, P., Van Gelderen, A., \& De Glopper, K. (2004b). Validating a test of second language written lexical retrieval: A new measure of fluency in written language production. Language Testing, 21, 174-201.

Spack, R (1997). The acquisition of academic literacy in a second language. A longitudinal case study. Written Communication, 14(1), 3-62.

Stapleton, P. (2005). Using the Web as a research source: Implications for L2 academic writing. M odern Language Journal, 89(2), 177-189.

Stevenson, M., Schoonen, R., \& De Glopper, K. (2006). Revising in two languages: A multi-dimensional comparison of online writing revisions in $\mathrm{L} 1$ and $\mathrm{FL}$. Journal of Second Language Writing, 15(3), 201-233. 
Storch, N. (2016). Collaborative writing. In R. M. M anchón \& P. K. M atsuda (Eds.), The handbook of second and foreign language writing (pp. 387-406). Berlin: de Gruyter M outon.

Takagaki, T. (2003). The revision patterns and intentions in L1 and L 2 by Japanese writers: A case study. TESL Canada Journal, 21(1), 22-37.

Teng, L. S., \& Zhang, L. (2016). A questionnaire-based validation of multidimensional models of self-regulated learning strategies. Modern Language Journal, 100 (3), 674-701.

Thorson, H. (2000). Using computer to compare foreign and native language writing processes: A statistical and case study approach. M odern Language Journal, 84(2), 155-170.

Tillema, M. (2012). Writing in first and second language: Empirical studies on text quality and writing processes. Utrecht: LOT Dissertation Series.

Tillema, M., van den Bergh, H., Rijlaarsdam, G., \& Sanders, T. (2011). Relating self reports of writing behavior and online task execution using a temporal model. Metacognition Learning, 6, 229-253

Van Gelderen, A., Oostdam, R., \& Van Schooten, E. (2011). Does foreign language writing benefit from increased lexical fluency? Evidence from a classroom experiment. Language Learning, 61(1), 281-321.

Van Weijen, D. (2009). Writing processes, text quality, and task effects; Empirical studies in first and second language writing. Utrecht: LOT Dissertation Series.

Vergaro, C. (2004). Discourse strategies of Italian and English sales promotion letters. English for Specific Purposes, 23(2), 181-207.

Williams, J. (2012). The potential role(s) of writing in second language development. Journal of Second Language Writing, 21, 321-331.

Zainuddin, H., \& M oore, R. A. (2003). Audience awareness in L1 and L2 composing of bilingual writers. TESL-EJ, 7(1). Retrieved from http://www-writing.berkeley.edu/TESL-EJ/ej25/a2.html

Zhang, L. (2013). Second language writing as and for second language learning. Journal of Second Language Writing, 22, 446-447.

Zimmermann, R. (2000). L2 writing subprocesses: A model of formulating and empirical findings. Learning and Instruction, 10(1), 73-99. 